\title{
Analisis Spasi Lubang Bor untuk Mengevaluasi Sumberdaya Timah Aluvial dan Mineral Ikutannya di Pulau Bangka dengan Global Estimation Variance
}

\author{
Raymond Kosher Sianturi $^{1}$, Mohamad Nur Heriawan ${ }^{2 *}$, Syafrizal $^{2}$ \\ ${ }^{1}$ Program Studi Magister Rekayasa Pertambangan, Fakultas Teknik Pertambangan dan Perminyakan, \\ Institut Teknologi Bandung \\ ${ }^{2}$ Kelompok Keahlian Eksplorasi Sumberdaya Bumi, Fakultas Teknik Pertambangan dan Perminyakan, \\ Institut Teknologi Bandung
}

\begin{abstract}
ABSTRAK Pulau Bangka merupakan daerah yang kaya akan mineralisasi timah yang dibawa oleh batuan granit. Selain kaya akan mineralisasi timah, ilmenite, rutile, anatase, zircon, monazite, dan xenotime juga hadir dalam batuan granit sebagai mineral aksesoris. Mineral-mineral ini juga terdapat dalam endapan sekunder timah aluvial dan disebut mineral ikutan timah (MIT). Optimasi spasi bor antara timah dan mineral ikutan timah dibutuhkan agar spasi tersebut dapat mewakili timah dan mineral ikutan timah. Metode yang digunakan pada penelitian ini adalah pendekatan geostatistik melalui metode Global Estimation Variance (GEV) untuk menghitung nilai relative error. Dari hasil penelitian didapatkan bahwa timah lebih homogen daripada mineral ikutan timah. Spasi optimum yang mewakili Sn (timah) dan mineral ikutan timah berdasarkan pada 8 (delapan) daerah di Pulau Bangka adalah 20 - 25 m untuk measured, 30 - 40 $\mathrm{m}$ untuk indicated, dan 40 - $50 \mathrm{~m}$ untuk inferred.
\end{abstract}

Kata Kunci: timah aluvial, mineral ikutan timah, spasi optimum, geostatistik, global estimation variance

Naskah masuk : 24 Juli 2020

Naskah direvisi : 7 Desember 2020

Naskah diterima : 11 Desember 2020

*Penulis korespondensi.

Email: heriawan@mining.itb.ac.id
ABSTRACT - Drill Hole Spacing Analysis for Evaluation of Tin and Associated Minerals Resources in Bangka Island Using Global Estimation Variance. Bangka Island is an area rich in granite rocks bearing tin mineralization. Besides that, ilmenite, rutile, anatase, zircon, monazite, and xenotime are also present in granite as mineral accessories. These minerals are also present in alluvial tin deposits and called as tin associated minerals. Optimization of drill hole spacing between tin and its associated minerals is indispensable so that these spacing can represent the spatial distribution of tin and its associated minerals. Global Estimation Variance (GEV) is used to calculate the relative error. This study showed that tin is more homogeneous than its associated minerals. The optimum spacings representing Sn (tin) and its associated minerals based on the case studies of eight sites at Bangka Island are 20-25 m, 30-40 m, and 40-50 m for obtaining the measured, indicated, and inferred resources, respectively.

Keywords: alluvial tin, tin associated minerals, optimum spacing, geostatistics, global estimation variance

\section{PENDAHULUAN}

Pulau Bangka merupakan bagian sabuk timah Asia Tenggara yang disusun oleh intrusi pluton granit yang kaya akan mineralisasi timah (Schwartz et al., 1995; Ng et al., 2017; Purwadi et al., 2020). Ilmenite, rutile, anatase, zircon, monazite, dan xenotime hadir pada batuan granit sebagai mineral aksesoris (Syafrizal et al., 2019a). Mineral-mineral tersebut juga terdapat pada endapan sekunder timah aluvial sebagai mineral 
ikutan timah (MIT) (Syafrizal et al, 2019b). Cassiterite, ilmenite, rutile, zircon, monazite, dan xenotime merupakan mineral berat yang dapat terendapkan pada endapan aluvial (placer) karena memiliki ketahanan terhadap pelapukan kimia, density yang tinggi, dan mechanical durability (Evans, 1993).

Monazite dan xenotime merupakan mineral sumber untuk rare earth elements (REEs) di endapan aluvial (placer) (Bern et al., 2016; Syafrizal et al., 2019). Mineral-mineral pembawa REEs seperti monazite dan xenotime dapat terkonsentrasi dalam endapan placer/sedimenter sebagai bagian dari kumpulan mineral berat karena tahan terhadap pelapukan dan memiliki density $4,8-5,5 \mathrm{gr} / \mathrm{cm}^{3}$ untuk mineral monazite dan $4,4-5,1 \mathrm{gr} / \mathrm{cm}^{3}$ untuk mineral xenotime (Bern et al., 2016). REEs dapat digunakan untuk peralatan berteknologi tinggi (Gwenzi et al., 2018). Ilmenite, rutile, dan anatase merupakan beberapa mineral pembawa titanium yang memiliki sifat fisik ringan, mengkilap, kuat, tahan panas, tidak beracun, dan tahan terhadap korosi yang dapat digunakan pada beberapa industri, seperti industri coating (Yu \& Wai, 2020). Zircon merupakan salah satu mineral pembawa zirconium yang memiliki sifat resisten dan tahan panas yang digunakan pada keramik, material tahan api, foundry, bahan kimia, dan reaktor nuklir (Perks \& Mudd, 2019). Penelitian terhadap mineral ikutan timah di Pulau Bangka dibutuhkan agar dapat dieksploitasi dan dimanfaatkan di masa yang akan datang.

Geostatistik merupakan ilmu yang mempelajari tentang teori dan pengaplikasian dari variabel teregional pada berbagai fenomena gejala alam (Matheron, 1971). Suatu variabel dikatakan teregional jika variabel tersebut terdistribusi di ruang dan mencirikan fenomena tertentu, contohnya adalah kadar mineral di zona mineralisasi. Geostatistik dapat digunakan untuk mengoptimasi spasi lubang bor dengan menggunakan metode Global Estimation Variance $(G E V)$ dan telah dilakukan oleh beberapa peneliti pada endapan batubara (Bertoli et al., 2013; Heriawan et al., 2020). GEV adalah konsep operasional dengan mengkarakterisasikan error yang berkaitan dengan pola pengambilan sampel tertentu dan geometri yang akan diestimasi (Bertoli et al., 2013). GEV menggunakan varians ekstensi untuk menghitung error ketika suatu blok diestimasi dengan menggunakan satu sampel yang terletak di tengah blok (Cornah et al., 2013).

Bertoli et al. pada tahun 2013 menggunakan GEV untuk optimasi spasi bor pada beberapa daerah di Bowen Basin dan membandingkannya dengan Australian Coal Guidelines. Heriawan et al. pada tahun 2020 juga menggunakan GEV untuk optimasi spasi bor di Cekungan Kutai dengan menggunakan data non-stationary dan membandingkannya dengan Standar Nasional Indonesia (SNI) 5015 tahun 2011 tentang pedoman pelaporan, sumberdaya, dan cadangan batubara. Dari hasil kedua penelitian ini, spasi optimum dari hasil GEV untuk sumberdaya measured lebih besar jika dibandingkan dengan Australian Coal Guidelines dan SNI. Sampai saat ini, penggunaan $G E V$ pada endapan aluvial belum pernah dilakukan.

Penentuan klasifikasi sumberdaya yang umum digunakan adalah search neighbourhoods $(50 \%$ dari recent reports), drill-hole spacing (30\% dari recent report) dan/atau kriging variance ( $6 \%$ dari recent report) (Silva \& Boisvert, 2014). Klasifikasi sumberdaya mineral dibagi menjadi measured, indicated, dan inferred yang tergantung pada tingkat keyakinan geologi (Battalgazy \& Madani, 2019; Isatelle \& Rivoirard, 2019). Hal ini didasarkan pada faktor-faktor yang berbeda seperti geometri atau model geologi, kualitas pengambilan sampel, dan jarak antara lubang bor (Isatelle \& Rivoirard, 2019). Jarak spasi lubang bor yang lebih rapat dapat mengurangi faktor ketidakpastian yang berhubungan dengan nilainilai estimasi (Cornah et al., 2013).

Penentuan spasi lubang bor untuk masing-masing klasifikasi sumberdaya yang dapat mewakili timah dan mineral ikutan timah belum ditentukan. Hal ini dibutuhkan agar mineral ikutan timah dapat dieksploitasi dan dimanfaatkan. Mengacu pada Permen ESDM No. 25/2018 tentang pengusahaan pertambangan mineral dan batubara serta Permen ESDM No. 26/2018 tentang pelaksanaan kaidah pertambangan yang baik dan pengawasan pertambangan mineral dan batubara, pemerintah mengamanahkan untuk melakukan konservasi mineral timah beserta mineral ikutannya. Penelitian untuk menentukan spasi bor optimum untuk timah dan mineral ikutannya dibutuhkan sehingga spasi bor tersebut dapat mewakili timah dan mineral ikutan timah. 


\section{METODE}

Metode penelitian yang dilakukan meliputi analisis statistik, analisis spasial, dan optimasi spasi bor dengan menggunakan GEV. Analisis statistik dilakukan untuk mengetahui variabilitas dari komoditas/mineral tanpa memperhatikan lokasi sampel/bor di daerah penelitian. Analisis spasial dilakukan dengan melihat range/daerah pengaruh dari variogram dan bertujuan untuk mengetahui variabilitas secara spasial dari komoditas/mineral di daerah penelitian. GEV digunakan untuk menghitung nilai relative error yang menunjukkan variabilitas secara global dari komoditas/mineral di daerah penelitian. Umumnya sebaran kadar pada endapan aluvial lebih bervariasi searah dengan aliran sungai dan pola spasi bor lebih rapat untuk yang searah dengan aliran. Namun pada penelitian ini karena daerah dengan keterdapatan data pemboran yang diperoleh tidak cukup luas dan dianggap tidak cukup mewakili untuk melihat anistropik di daerah penelitian, maka digunakan variogram omnidirectional dengan daerah pengaruh ke segala arah sama atau isotropik.

Penentuan spasi bor optimum untuk timah dan mineral ikutan timah dengan menggunakan $G E V$ dilakukan dengan menggunakan 3 pendekatan, yaitu: 1) berdasarkan kriteria Sinclair dan Blackwell (2002), 2) berdasarkan pedoman pengklasifikasian sumberdaya PT Timah Tbk., dan 3) berdasarkan nilai relative error. Hasil spasi bor optimum untuk timah dan mineral ikutan timah dari ke-3 pendekatan ini dibandingkan dan dianalisis untuk menentukan spasi bor yang mewakili timah dan mineral ikutan timah. Penentuan spasi bor yang mewakili timah dan mineral ikutan timah diambil dari spasi bor yang lebih kecil agar dapat mewakili semua komoditas/mineral tersebut.

\section{Data}

Data yang digunakan pada penelitian ini adalah data sekunder berupa data pemboran yang didapatkan dari PT Timah Tbk. Data pemboran ini berada pada 20 daerah di Pulau Bangka dan berjumlah 560 titik bor. Data yang digunakan merupakan data 2D yang berisi informasi koordinat titik bor yang telah ditransformasi menjadi koordinat lokal dan kadar yang dinotasikan dengan TDH (timah dihitung) dari Sn (timah) dan mineral ikutan timah (MIT). TDH (timah dihitung) adalah hasil perhitungan dari kekayaan (kadar) bijih atau mineral dan memiliki satuan $\mathrm{kg} / \mathrm{m}^{3}$.

Data bor di masing-masing daerah dipilih untuk dianalisis secara spasial dengan kriteria pola pemboran yang cukup teratur dan minimal terdapat 20 titik bor di daerah tersebut. Dari 20 daerah, 8 daerah yang memenuhi kriteria dan dapat dianalisis secara spasial. Contoh sebaran titik bor yang dapat dianalisis secara spasial dapat dilihat pada Gambar 1. Contoh sebaran titik bor yang tidak dapat dianalisis secara spasial pada Gambar 2.

\section{Statistik dan penentuan pencilan}

Data bor di masing-masing daerah yang memenuhi kriteria selanjutnya dilakukan analisis statistik univariate dan penentuan pencilan.

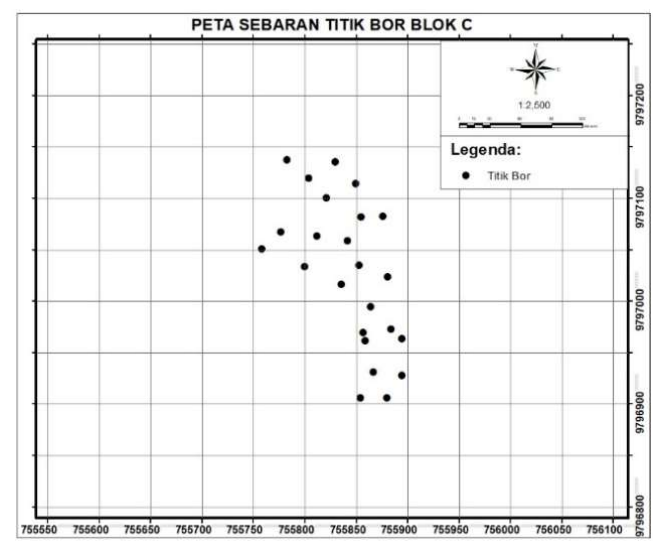

Gambar 1. Sebaran titik bor di Blok C.

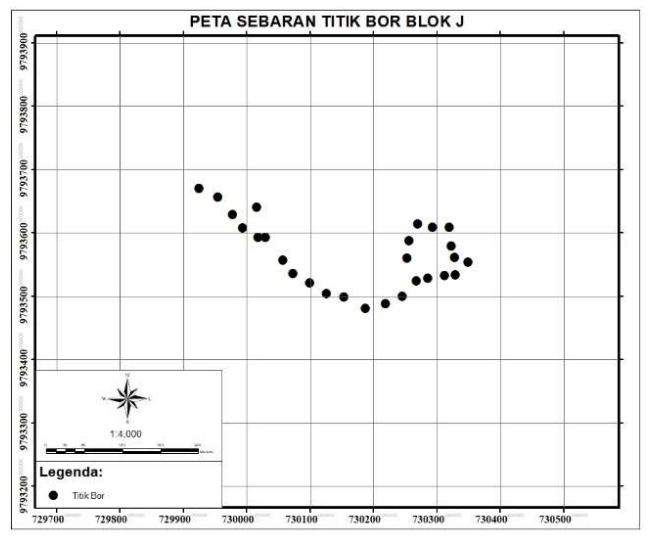

Gambar 2. Sebaran titik bor di Blok J. 
Analisis statistik univariate dilakukan untuk mengetahui parameter-parameter atau karakteristik populasi dari data kadar/TDH (timah dihitung) Sn (timah) dan mineral ikutan timah di setiap daerah. Komoditas/mineral yang akan dianalisis di masing-masing daerah minimal terdapat pada 10 lubang bor. Jika komoditas/mineral terdapat pada $<10$ lubang bor, komoditas/mineral tersebut tidak dianalisis. Hal ini karena daerah tersebut dianggap tidak memiliki prospek keterdapatan komoditas/mineral tersebut sehingga tidak dianalisis. Statistik univariate dari setiap komoditas/mineral yang akan dianalisis pada masing-masing daerah dapat dilihat pada Tabel 1.

Penentuan pencilan menggunakan nilai coefficient of variation ( $\mathrm{CoV}$ ). Jika nilai $\mathrm{CoV} \geq 1.5$, maka data tersebut dianggap memiliki pencilan dan jika nilai $\mathrm{CoV}<1.5$, maka data tersebut dianggap tidak memiliki pencilan. Contoh penentuan pencilan dilihat pada Gambar 3.

Tabel 1. Parameter statistik kadar atau TDH Sn (timah) dan mineral ikutan timah di setiap daerah.

\begin{tabular}{|c|c|c|c|c|c|c|c|c|}
\hline \multirow{2}{*}{ Daerah } & \multirow{2}{*}{$\begin{array}{l}\text { Komoditas/ } \\
\text { Mineral }\end{array}$} & \multicolumn{7}{|c|}{ TDH $\left(\mathrm{kg} / \mathrm{m}^{3}\right)$} \\
\hline & & Mean & Median & $\begin{array}{l}\text { Standard } \\
\text { Deviation }\end{array}$ & $\begin{array}{l}\text { Coefficient } \\
\text { of Variation }\end{array}$ & Minimum & Maximum & Count \\
\hline \multirow{4}{*}{ Blok A } & $\mathrm{Sn}$ & 0.017 & 0.005 & 0.032 & 1.850 & 0.001 & 0.130 & 20 \\
\hline & $\mathrm{Ilm}+\mathrm{Rut}+$ Ana & 0.023 & 0.012 & 0.031 & 1.315 & 0.003 & 0.118 & 20 \\
\hline & Mon & 0.001 & 0.000 & 0.003 & 2.093 & 0 & 0.011 & 20 \\
\hline & Zir & 0.013 & 0.006 & 0.020 & 1.530 & 0.002 & 0.095 & 20 \\
\hline \multirow{3}{*}{ Blok B } & $\mathrm{Sn}$ & 0.016 & 0.005 & 0.046 & 2.910 & 0 & 0.230 & 24 \\
\hline & $\mathrm{Ilm}+\mathrm{Rut}+\mathrm{Ana}$ & 0.067 & 0.025 & 0.092 & 1.364 & 0 & 0.349 & 24 \\
\hline & Zir & 0.002 & 0.000 & 0.003 & 1.731 & 0 & 0.014 & 24 \\
\hline \multirow{3}{*}{ Blok C } & $\mathrm{Sn}$ & 0.036 & 0.027 & 0.032 & 0.899 & 0 & 0.102 & 24 \\
\hline & $\mathrm{Ilm}+\mathrm{Rut}+\mathrm{Ana}$ & 0.116 & 0.102 & 0.089 & 0.770 & 0.028 & 0.447 & 24 \\
\hline & Zir & 0.030 & 0.017 & 0.029 & 0.961 & 0.001 & 0.107 & 24 \\
\hline \multirow{3}{*}{ Blok D } & $\mathrm{Sn}$ & 0.031 & 0.018 & 0.063 & 2.059 & 0.002 & 0.427 & 44 \\
\hline & $\mathrm{Ilm}+\mathrm{Rut}+\mathrm{Ana}$ & 0.040 & 0.029 & 0.042 & 1.032 & 0.002 & 0.211 & 44 \\
\hline & Zir & 0.040 & 0.009 & 0.143 & 3.552 & 0.001 & 0.954 & 44 \\
\hline \multirow{3}{*}{ Blok E } & $\mathrm{Sn}$ & 0.023 & 0.007 & 0.038 & 1.654 & 0 & 0.156 & 27 \\
\hline & $\mathrm{Ilm}+\mathrm{Rut}+\mathrm{Ana}$ & 0.007 & 0.006 & 0.006 & 0.981 & 0 & 0.023 & 27 \\
\hline & Zir & 0.019 & 0.013 & 0.020 & 1.068 & 0 & 0.067 & 27 \\
\hline \multirow{3}{*}{ Blok F } & $\mathrm{Sn}$ & 0.008 & 0.003 & 0.012 & 1.518 & 0 & 0.044 & 28 \\
\hline & $\mathrm{Ilm}+\mathrm{Rut}+\mathrm{Ana}$ & 0.031 & 0.016 & 0.039 & 1.247 & 0.002 & 0.145 & 28 \\
\hline & Zir & 0.014 & 0.002 & 0.033 & 2.374 & 0 & 0.150 & 28 \\
\hline \multirow{3}{*}{ Blok G } & $\mathrm{Sn}$ & 0.015 & 0.003 & 0.041 & 2.715 & 0 & 0.211 & 29 \\
\hline & $\mathrm{Ilm}+\mathrm{Rut}+\mathrm{Ana}$ & 0.100 & 0.076 & 0.089 & 0.895 & 0 & 0.409 & 29 \\
\hline & Zir & 0.0004 & 0 & 0.001 & 3.184 & 0 & 0.008 & 29 \\
\hline \multirow{3}{*}{ Blok H } & $\mathrm{Sn}$ & 0.041 & 0.020 & 0.094 & 2.312 & 0.004 & 0.496 & 26 \\
\hline & $\mathrm{Ilm}+\mathrm{Rut}+\mathrm{Ana}$ & 0.010 & 0.008 & 0.006 & 0.600 & 0.001 & 0.024 & 26 \\
\hline & Zir & 0.015 & 0.011 & 0.013 & 0.868 & 0 & 0.049 & 26 \\
\hline
\end{tabular}



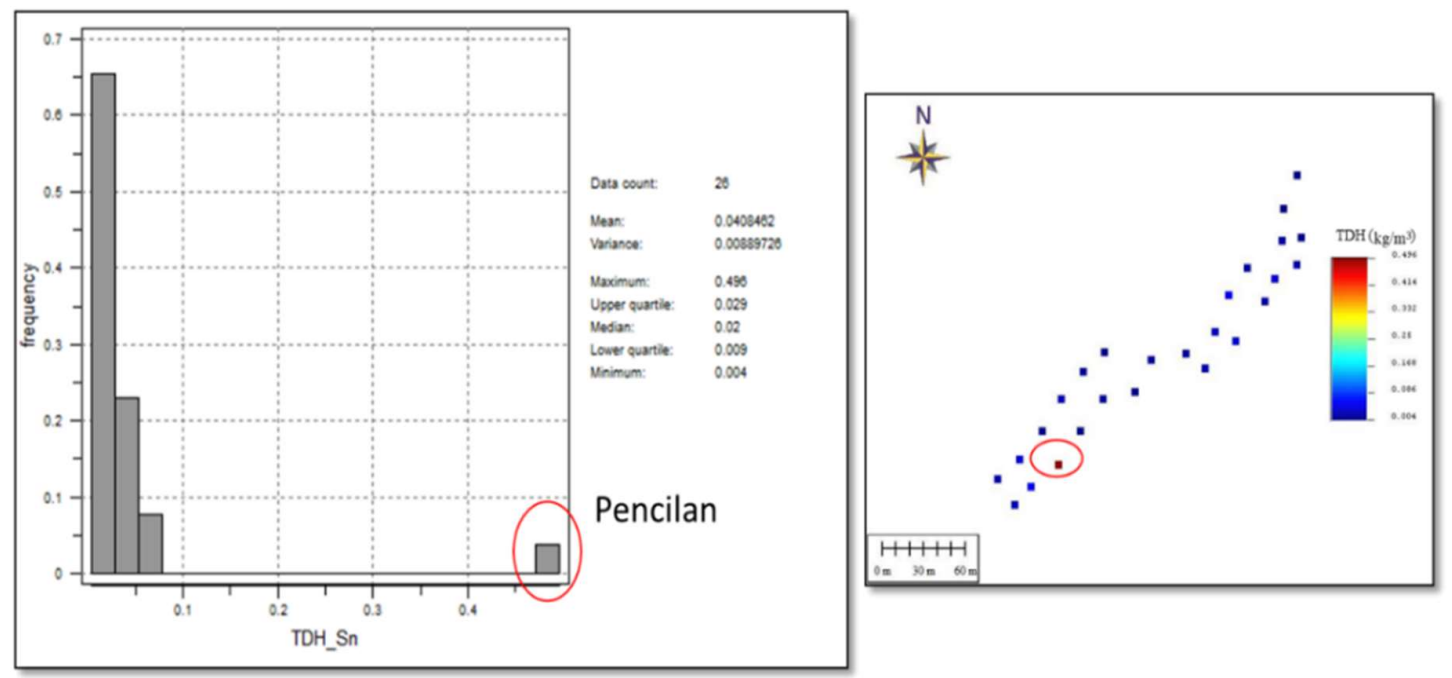

Gambar 3. Contoh penentuan pencilan Sn (timah). Catatan: lingkaran merah merupakan pencilan

\section{Variogram}

Analisis spasial dengan menggunakan variogram dilakukan dengan tujuan untuk mengetahui homogenitas yang dapat ditunjukan oleh range/daerah pengaruh (a) variogram dari komoditas/mineral di daerah penelitian. Variogram digunakan untuk melihat variabilitas antara 2 data yang dipisahkan oleh suatu jarak di suatu daerah. Variogram dihitung dengan rumus perbedaan rata-rata antara dua titik conto dengan jarak tertentu. Secara matematis dapat dinyatakan dengan persamaan berikut:

$$
\gamma(\mathrm{h})=\frac{\sum_{i=1}^{n}[Z(X i)-Z(X i+h)]^{2}}{2 \mathrm{~N}(\mathrm{~h})}
$$

dimana $\quad \gamma(\mathrm{h}) \quad$ merupakan variogram eksperimental, $Z(X i)$ adalah nilai pada lokasi $(X i), Z(X i+h)$ adalah nilai pada lokasi $(X i)$ yang dipisahkan oleh jarak (h).

Pembuatan dan fitting variogram menggunakan software SGeMS. Variogram yang digunakan adalah variogram omnidirectional dengan arah $\mathrm{N} 0^{\circ} \mathrm{E}$ dan toleransi sudut $90^{\circ}$. Fitting pada variogram menggunakan model spherical dan dilakukan untuk mengetahui parameter-parameter pada variogram seperti nugget effect $\left(\mathrm{C}_{0}\right)$, range/daerah pengaruh $(a)$, dan sill $\left(\mathrm{C}_{0}+\mathrm{C}_{1}\right)$. Sill pada variogram di-set agar mendekati nilai variance dari data. Contoh variogram dari masingmasing komoditas/mineral dapat dilihat pada
Gambar 4. Parameter variogram hasil fitting dari setiap komoditas/mineral pada masing-masing daerah dapat dilihat pada Tabel 2.

\section{Perhitungan relative error menggunakan GEV}

Sebelum melakukan optimasi spasi bor, perhitungan nilai relative error dengan menggunakan Global Estimation Variance (GEV) dilakukan terlebih dahulu. Metode $G E V$ digunakan untuk mencari nilai relative error secara global di suatu daerah. Pada penelitian ini digunakan 5 skenario spasi bor untuk menentukan spasi bor optimum di masing-masing daerah. Variasi spasi bor yang digunakan adalah $20 \mathrm{~m}, 30$ $\mathrm{m}, 40 \mathrm{~m}, 50 \mathrm{~m}$, dan $60 \mathrm{~m}$. Masing-masing skenario spasi pemboran akan dihitung nilai relative error.

Untuk menghitung varians estimasi menggunakan rumus di bawah ini:

$$
\sigma^{2}{ }_{e}=2 \bar{\gamma}(S, V)-\bar{\gamma}(V, V)-\bar{\gamma}(S, S)
$$

dimana $\sigma^{2}{ }_{e}$ adalah varians estimasi, $\bar{\gamma}(S, V)$ adalah nilai variogram rata-rata titik ke blok, $\bar{\gamma}(V, V)$ adalah nilai variogram rata-rata blok ke blok, dan $\bar{\gamma}(S, S)$ adalah nilai variogram titik ke titik.

Untuk menghitung Global Estimation Variance $(G E V)$ menggunakan rumus di bawah ini:

$$
G E V=\frac{\sigma^{2} e}{N}
$$



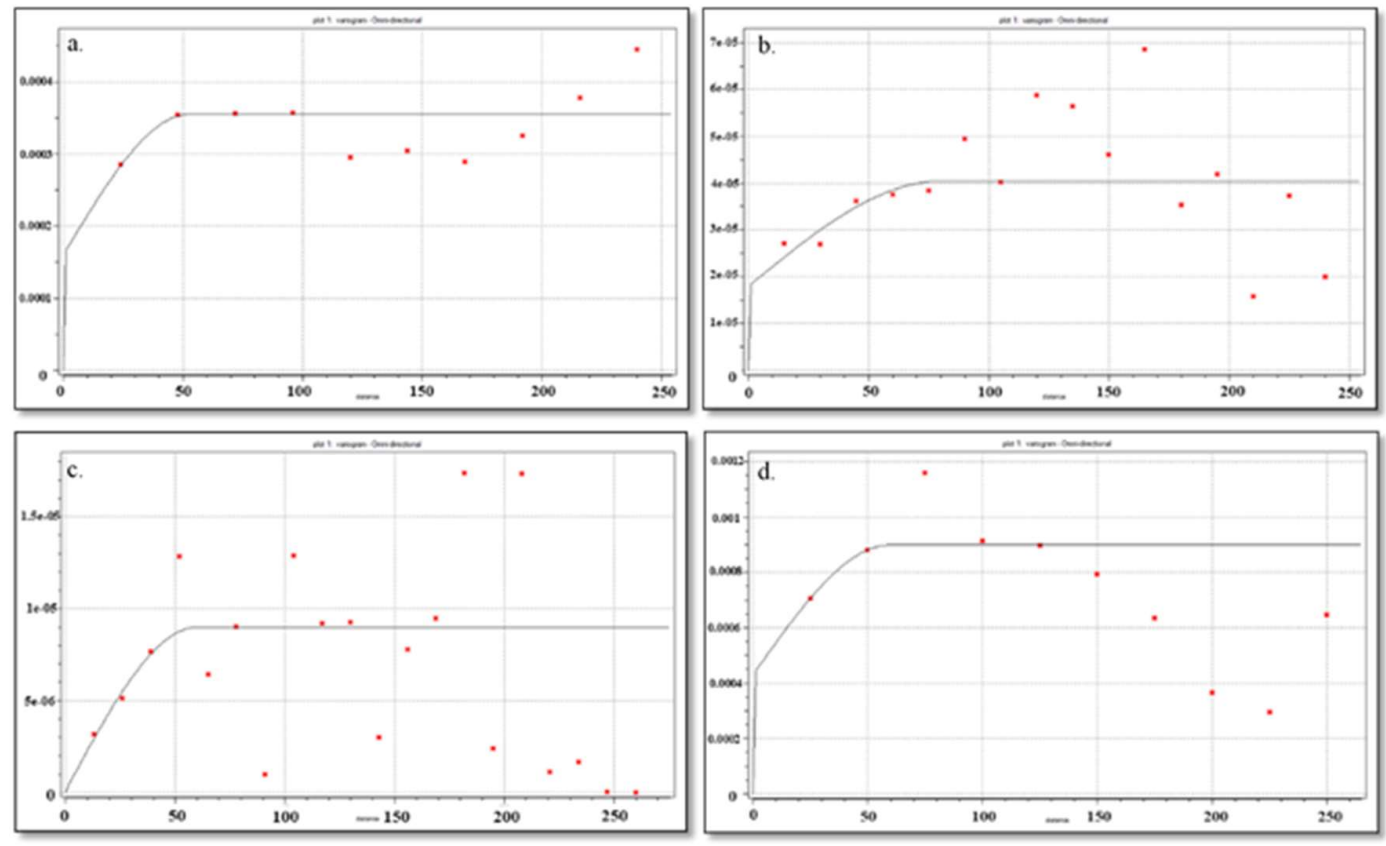

Gambar 4. Contoh variogram, a. Sn (timah), b. Ilmenite+Rutile+Anatase, c. Monazite, dan d. Zircon.

dimana GEV adalah Global Estimation Variance, $\sigma^{2}{ }_{e}$ adalah varians estimasi, dan $N$ adalah jumlah blok di suatu luasan daerah atau area. Untuk luas area dan jumlah $N$ pada setiap skenario spasi bor pada masing-masing daerah dapat dilihat pada Tabel 3 .

Dengan menggunakan asumsi tingkat kepercayaan (confidence level) pada penelitian ini adalah $95 \%$, nilai relative error dihitung dengan menggunakan rumus:

$$
\text { relative error }=\frac{ \pm 2 \sqrt{G E V}}{\bar{Z}} \times 100 \%
$$

dimana relative error adalah nilai relative error, $G E V$ adalah Global Estimation Variance, dan $\bar{Z}$ adalah nilai rata-rata (mean). Untuk spasi bor yang lebih besar dari skenario spasi bor, perhitungan nilai relative error menggunakan ekstrapolasi dengan regresi linear.

\section{Optimasi spasi lubang bor}

Optimasi spasi bor atau Drill-Hole Spacing Analysis (DHSA) adalah teknik geostatistik yang menggunakan $G E V$ untuk menghitung tingkat presisi pada berbagai kerapatan atau spasi sampel untuk endapan tertentu (Journel dan Huijbregts, 1978; Geovariances, 2016). Pada penelitian ini, optimasi spasi bor dilakukan menggunakan 3 (tiga) pendekatan, yaitu: 1) berdasarkan kriteria Sinclair dan Blackwell (2002), 2) berdasarkan pedoman pengklasifikasian sumberdaya PT Timah Tbk., dan 3) berdasarkan nilai relative error. Penentuan spasi bor optimum untuk Sn (timah) diambil dari spasi optimum rata-rata (mean), sedangkan untuk mineral ikutan timah spasi bor optimum diambil dari spasi optimum rata-rata (mean) terkecil antara mineral ikutan timah. Hasil spasi bor optimum ini akan cukup mewakili Sn (timah) dan mineral ikutan timah dengan asumsi distribusi spasi bor dan relative error adalah normal.

\section{Berdasarkan kriteria Sinclair dan Blackwell (2002)}

Pengklasifikasian nilai relative error pada masing-masing klasifikasi sumberdaya untuk endapan aluvial sampai saat ini belum ada. Oleh karena itu, pada penelitian ini menggunakan pengklasifikasian nilai relative error untuk masing-masing klasifikasi sumberdaya berdasarkan kriteria Sinclair dan Blackwell (2002). Pengklasifikasian nilai relative error ini untuk endapan porfiri $\mathrm{Cu}$ dan epitermal Au. Nilai relative error dari hasil perhitungan menggunakan $G E V$ selanjutnya di-plot ke dalam bentuk grafik 
Tabel 2. Parameter variogram setiap komoditas/mineral di masing-masing daerah.

\begin{tabular}{|c|c|c|c|c|c|}
\hline \multicolumn{2}{|c|}{ Parameter Variogram } & \multirow{2}{*}{$\begin{array}{l}\mathbf{C}_{\mathbf{0}} \\
0.000001\end{array}$} & \multirow{2}{*}{$\begin{array}{l}\mathbf{C}_{\mathbf{1}} \\
0.000137\end{array}$} & \multirow{2}{*}{$\begin{array}{c}\text { Nugget Ratio } \\
0.7 \%\end{array}$} & \multirow{2}{*}{$\begin{array}{r}a(\mathbf{m}) \\
85\end{array}$} \\
\hline \multirow{4}{*}{ Blok A } & Sn & & & & \\
\hline & $\mathrm{Ilm}+\mathrm{Rut}+\mathrm{Ana}$ & 0.00001 & 0.00099 & $1 \%$ & 70 \\
\hline & Mon & 0.0000001 & 0.0000089 & $1 \%$ & 60 \\
\hline & Zir & 0.000035 & 0.0000205 & $63 \%$ & 55 \\
\hline \multirow{3}{*}{ Blok B } & Sn & 0.000038 & 0.000019 & $67 \%$ & 118 \\
\hline & $\mathrm{Ilm}+\mathrm{Rut}+$ Ana & 0.006 & 0.002 & $75 \%$ & 68 \\
\hline & Zir & 0.0000025 & 0.00000082 & $75 \%$ & 20 \\
\hline \multirow{3}{*}{ Blok C } & Sn & 0.0001 & 0.00097 & $9 \%$ & 70 \\
\hline & $\mathrm{Ilm}+\mathrm{Rut}+\mathrm{Ana}$ & 0.0055 & 0.0024 & $70 \%$ & 45 \\
\hline & Zir & 0.00043 & 0.00047 & $48 \%$ & 60 \\
\hline \multirow{3}{*}{ Blok D } & Sn & 0.0002 & 0.000056 & $78 \%$ & 85 \\
\hline & $\mathrm{Ilm}+\mathrm{Rut}+\mathrm{Ana}$ & 0.0005 & 0.00123 & $29 \%$ & 65 \\
\hline & Zir & 0.00033 & 0.00025 & $57 \%$ & 95 \\
\hline \multirow{3}{*}{ Blok E } & Sn & 0.00016 & 0.000195 & $45 \%$ & 53 \\
\hline & $\mathrm{Ilm}+\mathrm{Rut}+$ Ana & 0.000018 & 0.0000224 & $45 \%$ & 80 \\
\hline & Zir & 0.00012 & 0.00026 & $32 \%$ & 80 \\
\hline \multirow{3}{*}{ Blok F } & Sn & 0.000008 & 0.000015 & $35 \%$ & 30 \\
\hline & $\mathrm{Ilm}+\mathrm{Rut}+\mathrm{Ana}$ & 0.0005 & 0.00117 & $30 \%$ & 45 \\
\hline & Zir & 0.000055 & 0.000016 & $77 \%$ & 20 \\
\hline \multirow{3}{*}{ Blok G } & Sn & 0.00001 & 0.000059 & $14 \%$ & 120 \\
\hline & $\mathrm{Ilm}+\mathrm{Rut}+\mathrm{Ana}$ & 0.000059 & 0.00765 & $0.8 \%$ & 90 \\
\hline & Zir & 0.0000005 & 0.0000018 & $22 \%$ & 160 \\
\hline \multirow{3}{*}{ Blok H } & Sn & 0.00012 & 0.00018 & $40 \%$ & 63 \\
\hline & $\mathrm{Ilm}+\mathrm{Rut}+\mathrm{Ana}$ & 0.000006 & 0.00003 & $17 \%$ & 90 \\
\hline & Zir & 0.000025 & 0.000165 & $13 \%$ & 76 \\
\hline
\end{tabular}

agar lebih memudahkan untuk penentuan spasi bor optimum. Berikut ini merupakan pengklasifikasian sumberdaya dengan relative error berdasarkan kriteria Sinclair dan Blackwell (2002).

$$
\text { Measured } 30 \% \leq \text { Indicated } 50 \% \leq \text { Inferred }
$$

Optimasi spasi bor berdasarkan kriteria Sinclair dan Blackwell (2002) yang dilakukan pada penelitian menggunakan nilai relative error $<$ $30 \%, 30 \%-50 \%$, dan $>50 \%$ berturut-turut untuk kategori measured, indicated, dan inferred. Contoh grafik penentuan spasi optimum untuk setiap klasifikasi sumberdaya pada masingmasing komoditas/mineral berdasarkan pendekatan ini dapat dilihat pada Gambar 5.
Untuk spasi optimum masing-masing komoditas/mineral di setiap daerah berdasarkan pendekatan ini dapat dilihat pada Tabel 4 .

\section{Berdasarkan pedoman pengklasifikasian sumberdaya PT Timah Tbk.}

Pedoman pengklasifikasian sumberdaya yang dilakukan oleh PT Timah Tbk. pada endapan aluvial menggunakan analisa variogram khususnya range/daerah pengaruh. Pedoman pengklasifikasian sumberdaya PT Timah Tbk. untuk endapan aluvial adalah:

- $\quad<2 / 3$ range untuk measured

- $2 / 3$ dan $<1$ range untuk indicated

- 1 range untuk inferred 
Tabel 3. Luas daerah dan jumlah $\mathrm{N}$ pada setiap skenario spasi bor.

\begin{tabular}{|c|c|c|c|c|c|c|}
\hline \multirow{2}{*}{ Daerah } & \multirow{2}{*}{ Luas Daerah } & \multicolumn{5}{|c|}{ Jumlah N Setiap Skenario Spasi Bor } \\
\hline & & $20 \mathrm{~m}$ & $30 \mathrm{~m}$ & $40 \mathrm{~m}$ & $50 \mathrm{~m}$ & $60 \mathrm{~m}$ \\
\hline Blok A & $120 \mathrm{~m} \times 260 \mathrm{~m}$ & 78 & 36 & 21 & 18 & 10 \\
\hline Blok B & $160 \mathrm{~m} \times 340 \mathrm{~m}$ & 136 & 72 & 36 & 28 & 18 \\
\hline Blok C & $160 \mathrm{~m} \times 260 \mathrm{~m}$ & 104 & 54 & 28 & 24 & 15 \\
\hline Blok D & $260 \mathrm{~m} \times 240 \mathrm{~m}$ & 156 & 72 & 42 & 30 & 20 \\
\hline Blok E & $200 \mathrm{~m} \times 200 \mathrm{~m}$ & 100 & 49 & 25 & 16 & 16 \\
\hline Blok F & $280 \mathrm{~m} \times 220 \mathrm{~m}$ & 154 & 80 & 42 & 30 & 20 \\
\hline Blok G & $380 \mathrm{~m} \times 340 \mathrm{~m}$ & 323 & 156 & 90 & 56 & 42 \\
\hline Blok H & $240 \mathrm{~m} \times 240 \mathrm{~m}$ & 144 & 64 & 36 & 25 & 16 \\
\hline
\end{tabular}

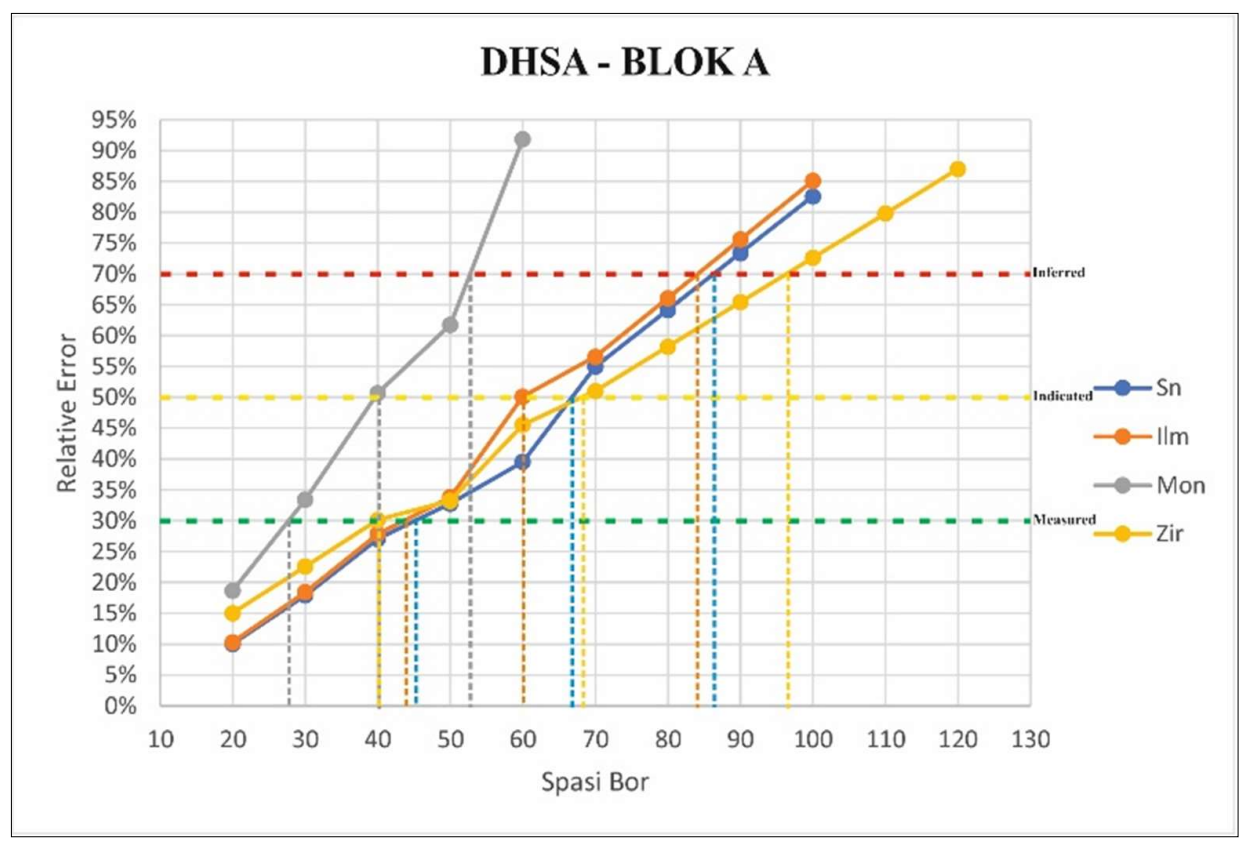

Gambar 5. Penentuan spasi bor optimum berdasarkan kriteria Sinclair dan Blackwell di daerah Blok A.

Optimasi spasi bor berdasarkan pedoman pengklasifikasian sumberdaya PT Timah Tbk. yang dilakukan pada penelitian ini adalah $2 / 3$ range, 1 range, dan $>1$ range berturut-turut untuk kategori measured, indicated, dan inferred. Untuk spasi optimum masing-masing komoditas/mineral di setiap daerah berdasarkan pendekatan ini dapat dilihat pada Tabel 5 .

\section{Berdasarkan relative error}

Pendekatan berdasarkan relative error merupakan modifikasi dari pendekatan ke-2. Sebelum melakukan optimasi spasi bor dengan menggunakan pendekatan ini, dilakukan perhitungan dan penentuan nilai relative error untuk masing-masing klasifikasi sumberdaya pada endapan aluvial berdasarkan spasi bor optimum dengan menggunakan pedoman pengklasifikasian 
Tabel 4. Spasi optimum berdasarkan kriteria Sinclair dan Blackwell (2002).

\begin{tabular}{llccc}
\hline Daerah & Komoditas/ Mineral & $\begin{array}{c}\text { Measured } \\
\mathbf{( 3 0 \% )}\end{array}$ & $\begin{array}{c}\text { Indicated } \\
\mathbf{( 5 0 \% )}\end{array}$ & $\begin{array}{c}\text { Inferred } \\
\mathbf{( 7 0 \% )}\end{array}$ \\
\hline \multirow{3}{*}{ Blok A } & Sn & 45 & 65 & 85 \\
& Ilm+Rut+Ana & 40 & 60 & 80 \\
& Mon & 25 & 40 & 50 \\
Blok B & Zir & 40 & 65 & 95 \\
& Sn & 35 & 65 & 90 \\
& Ilm+Rut+Ana & - & - & - \\
Blok C & Zir & - & - & - \\
& Sn & 60 & 100 & 135 \\
& Ilm+Rut+Ana & 50 & 90 & 125 \\
Blok D & Zir & 40 & 70 & 100 \\
\hline \multirow{3}{*}{ Blok E } & Sn & - & - & - \\
& Ilm+Rut+Ana & 55 & 85 & 120 \\
\hline \multirow{3}{*}{ Blok F } & Zir & 35 & 65 & 90 \\
& Sn & 30 & 45 & 65 \\
& Ilm+Rut+Ana & 40 & 75 & 105 \\
\hline \multirow{3}{*}{ Blok G } & Zir & 40 & 75 & 105 \\
& Sn & 40 & 60 & 85 \\
\hline \multirow{3}{*}{ Blok H } & Ilm+Rut+Ana & 40 & 60 & 85 \\
& Zir & - & - & - \\
\hline & Sn & 65 & 105 & 150 \\
& Ilm+Rut+Ana & 115 & 190 & 260 \\
& Zir & 30 & 50 & 70 \\
\hline & Sn & 60 & 100 & 135 \\
& Zir & 90 & 150 & 210 \\
& & 60 & 100 & 140 \\
\hline & & & &
\end{tabular}

sumberdaya yang dilakukan oleh PT Timah Tbk. Nilai relative error yang digunakan adalah hasil dari perhitungan dengan menggunakan $G E V$. Untuk nilai relative error masing-masing klasifikasi sumberdaya dapat dilihat pada Tabel 6.

Penentuan nilai relative error untuk masingmasing klasifikasi sumberdaya pada endapan aluvial diambil dari pembulatan nilai rata-rata (mean) relative error terkecil antara Sn (timah) dan mineral ikutan timah. Relative error untuk masing-masing klasifikasi sumberdaya adalah $20 \%, 35 \%$, dan $55 \%$ berturut-turut untuk kategori measured, indicated, dan inferred.

Selanjutnya dilakukan optimasi spasi bor berdasarkan nilai relative error yang telah diperoleh tersebut. Nilai relative error dari hasil perhitungan menggunakan $G E V$ selanjutnya diplot ke dalam bentuk grafik agar lebih memudahkan untuk penentuan spasi bor optimum. Contoh grafik penentuan spasi optimum untuk setiap klasifikasi sumberdaya pada masingmasing komoditas/mineral berdasarkan pendekatan ini dapat dilihat pada Gambar 6 . Untuk spasi optimum masing-masing komoditas/mineral di setiap daerah berdasarkan pendekatan ini dapat dilihat pada Tabel 7.

\section{HASIL DAN DISKUSI}

\section{Analisis statistik}

Berdasarkan analisis statistik univariate pada Tabel 1, komoditas/mineral yang paling dominan pada 8 (delapan) daerah di Pulau Bangka adalah Sn (timah) dan ilmenite+rutile+anatase. Hal ini dapat dilihat pada kadar atau TDH rata-rata (mean) pada masing-masing daerah dimana $\mathrm{Sn}$ 
Tabel 5. Spasi optimum berdasarkan pedoman pengklasifikasian sumberdaya PT Timah Tbk.

\begin{tabular}{|c|c|c|c|c|c|}
\hline Daerah & $\begin{array}{l}\text { Komoditas/ } \\
\text { Mineral }\end{array}$ & $\begin{array}{c}\text { Range awal } \\
\text { (a) }\end{array}$ & $\begin{array}{l}\text { Measured } \\
2 / 3 a\end{array}$ & $\begin{array}{c}\text { Indicated } \\
a\end{array}$ & $\begin{array}{c}\text { Inferred } \\
\quad 1.5 a\end{array}$ \\
\hline \multirow{4}{*}{ Blok A } & $\mathrm{Sn}$ & 85 & 55 & 85 & 125 \\
\hline & $\mathrm{Ilm}+\mathrm{Rut}+\mathrm{Ana}$ & 70 & 45 & 70 & 105 \\
\hline & Mon & 60 & 40 & 60 & 90 \\
\hline & Zir & 55 & 35 & 55 & 80 \\
\hline \multirow{3}{*}{ Blok B } & $\mathrm{Sn}$ & 118 & 75 & 115 & 175 \\
\hline & $\mathrm{Ilm}+\mathrm{Rut}+\mathrm{Ana}$ & 68 & - & - & - \\
\hline & Zir & 20 & - & - & - \\
\hline \multirow{3}{*}{ Blok C } & $\mathrm{Sn}$ & 70 & 45 & 70 & 105 \\
\hline & $\mathrm{Ilm}+\mathrm{Rut}+\mathrm{Ana}$ & 45 & 30 & 45 & 65 \\
\hline & Zir & 60 & 40 & 60 & 90 \\
\hline \multirow{3}{*}{ Blok D } & $\mathrm{Sn}$ & 85 & - & - & - \\
\hline & $\mathrm{Ilm}+\mathrm{Rut}+\mathrm{Ana}$ & 65 & 40 & 65 & 95 \\
\hline & Zir & 95 & 60 & 95 & 140 \\
\hline \multirow{3}{*}{ Blok E } & $\mathrm{Sn}$ & 53 & 35 & 50 & 80 \\
\hline & $\mathrm{Ilm}+\mathrm{Rut}+\mathrm{Ana}$ & 80 & 50 & 80 & 120 \\
\hline & Zir & 80 & 50 & 80 & 120 \\
\hline \multirow{3}{*}{ Blok F } & $\mathrm{Sn}$ & 30 & 20 & 30 & 45 \\
\hline & $\mathrm{Ilm}+\mathrm{Rut}+\mathrm{Ana}$ & 45 & 30 & 45 & 65 \\
\hline & Zir & 20 & - & - & - \\
\hline \multirow{3}{*}{ Blok G } & $\mathrm{Sn}$ & 120 & 80 & 120 & 180 \\
\hline & $\mathrm{Ilm}+\mathrm{Rut}+\mathrm{Ana}$ & 90 & 60 & 90 & 135 \\
\hline & Zir & 160 & 105 & 160 & 240 \\
\hline \multirow{3}{*}{ Blok H } & $\mathrm{Sn}$ & 63 & 40 & 60 & 95 \\
\hline & $\mathrm{Ilm}+\mathrm{Rut}+\mathrm{Ana}$ & 90 & 60 & 90 & 135 \\
\hline & Zir & 76 & 50 & 75 & 115 \\
\hline
\end{tabular}

Tabel 6. Nilai relative error masing-masing klasifikasi sumberdaya untuk setiap komoditas/mineral.

\begin{tabular}{lllllll}
\hline \multirow{2}{*}{$\begin{array}{l}\text { Komoditas/ } \\
\text { Mineral }\end{array}$} & \multicolumn{2}{c}{ Measured } & \multicolumn{2}{c}{ Relative error (\%) } \\
\cline { 2 - 7 } & Range & Mean & Range & Mean & Range & Mean \\
\hline Sn & $13-56$ & 31 & $20-85$ & 50 & $33-129$ & 76 \\
Ilm+Rut+Ana & $14-36$ & 23 & $22-57$ & 37 & $35-90$ & 56 \\
Mon & 51 & 51 & 92 & 92 & 139 & 139 \\
Zir & $21-104$ & 44 & $36-159$ & 67 & $57-240$ & 100 \\
\hline
\end{tabular}




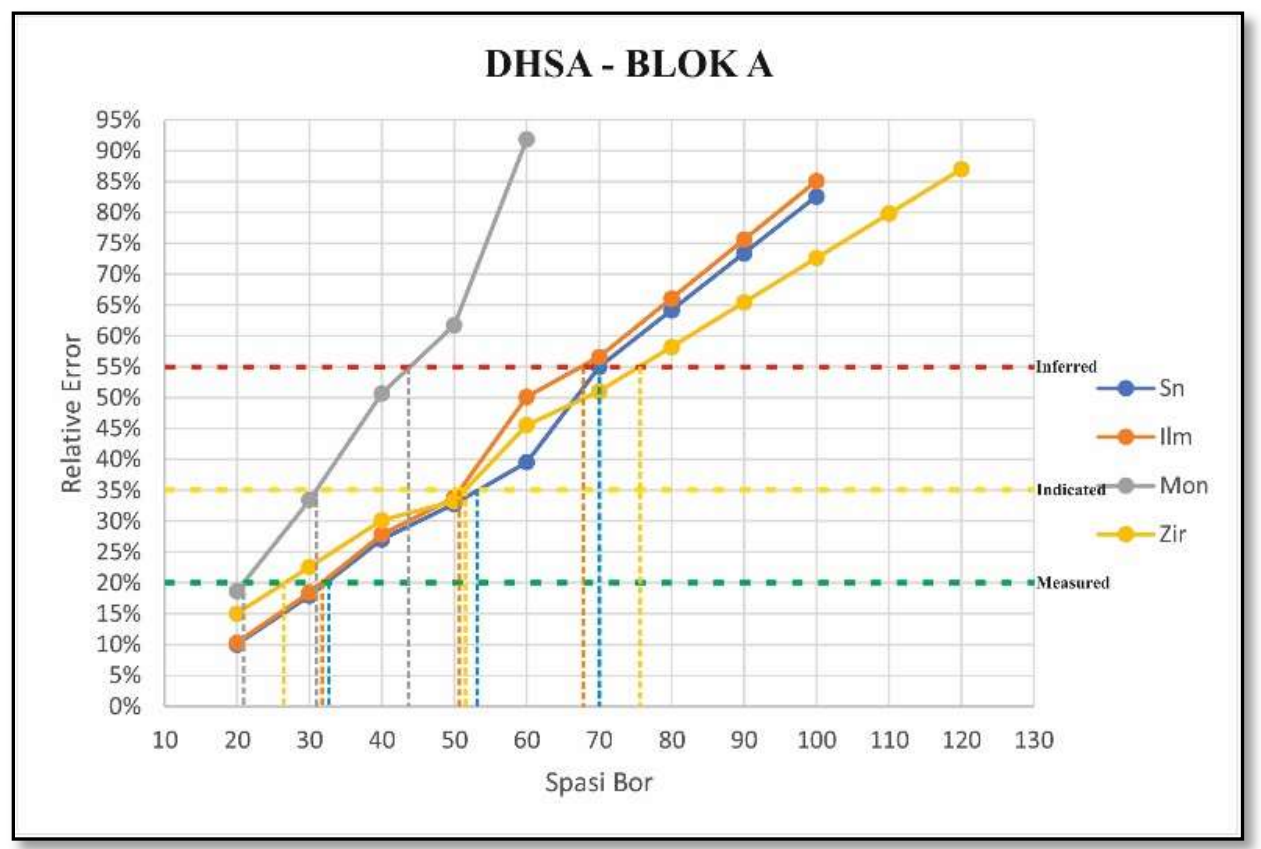

Gambar 6. Penentuan spasi bor optimum berdasarkan relative error di daerah Blok A.

dan ilmenite +rutile+anatase memiliki nilai mean yang lebih tinggi. Sn (timah) dominan di 2 (dua) lokasi, yaitu Blok E, dan Blok $\mathrm{H}$, sedangkan ilmenite+rutile+anatase dominan di 6 (enam) lokasi, yaitu Blok A, Blok B, Blok C, Blok D, Blok F, dan Blok G.

Komoditas/mineral yang selalu terdapat pada $>10$ lubang bor di daerah penelitian adalah Sn (timah), ilmenite+rutile+anatase, dan zircon. Mineral ikutan timah pembawa REEs seperti monazite dan xenotime di daerah penelitian terdapat pada $\leq 10$ lubang bor. Monazite terdapat pada 10 lubang bor dari 20 bor berada pada daerah Blok A dengan kadar rata-rata (mean) sebesar $0.001 \mathrm{~kg} / \mathrm{m}^{3}$. Selain itu, di daerah lainnya monazite hanya terdapat pada $\leq 5$ lubang bor. Untuk xenotime terdapat dalam jumlah yang lebih kecil daripada monazite. Xenotime hanya terdapat pada $\leq 2$ lubang bor.

Secara keseluruhan, monazite lebih bervariasi daripada Sn (timah) dan mineral ikutan timah lainnya. Hal ini dapat dilihat pada Tabel 8, dimana nilai rata-rata coefficient of variation $(\mathrm{CoV})$ dari monazite lebih besar daripada Sn (timah) dan mineral ikutan timah lainnya. Namun, terdapat komoditas/mineral yang lebih bervariasi daripada monazite seperti Sn (timah) di Blok B, Blok G, dan
Blok H serta Zircon di Blok D, Blok F, dan Blok G.

Jika dilihat dari histogram, semua data kadar yang dinotasikan oleh TDH (timah dihitung) Sn (timah) dan mineral ikutan timah di daerah penelitian menunjukkan distribusi lognormal. Histogram dengan distribusi lognormal menunjukkan bahwa nilai mean dari data lebih besar dari nilai median dari data. Nilai $C o V$ dari semua data yang menunjukkan nilai $>0.5$ juga membuktikan bahwa semua data yang digunakan memiliki distribusi lognormal.

\section{Analisis spasial (Variogram)}

Berdasarkan parameter variogram pada Tabel 2, nilai range/daerah pengaruh $\mathrm{Sn}$ (timah) dan mineral ikutan timah berkisar antara $20-160 \mathrm{~m}$. Untuk nugget ratio berkisar antara $0.7-78 \%$. Hal ini menunjukkan bahwa masih terdapat beberapa komoditas/mineral di daerah penelitian yang memiliki nugget ratio yang tinggi atau extreme nugget effect $(\geq 75 \%)$. Nugget ratio yang tinggi ini dapat diakibatkan oleh spasi pengambilan sampel/bor kurang rapat dan pola pengambilan sampel yang belum teratur. Untuk lokasi-lokasi yang memiliki extreme nugget effect 
Tabel 7. Spasi optimum berdasarkan relative error.

\begin{tabular}{|c|c|c|c|c|}
\hline Daerah & $\begin{array}{l}\text { Komoditas/ } \\
\text { Mineral }\end{array}$ & Measured (20\%) & Indicated (35\%) & Inferred $(55 \%)$ \\
\hline \multirow{4}{*}{ Blok A } & $\mathrm{Sn}$ & 30 & 50 & 70 \\
\hline & $\mathrm{Ilm}+\mathrm{Rut}+$ Ana & 30 & 50 & 65 \\
\hline & Mon & 20 & 30 & 40 \\
\hline & Zir & 25 & 50 & 75 \\
\hline \multirow{3}{*}{ Blok B } & $\mathrm{Sn}$ & 25 & 45 & 70 \\
\hline & $\mathrm{Ilm}+\mathrm{Rut}+$ Ana & - & - & - \\
\hline & Zir & - & - & - \\
\hline \multirow{3}{*}{ Blok C } & $\mathrm{Sn}$ & 45 & 70 & 110 \\
\hline & $\mathrm{Ilm}+\mathrm{Rut}+$ Ana & 30 & 55 & 95 \\
\hline & Zir & 30 & 50 & 80 \\
\hline \multirow{3}{*}{ Blok D } & $\mathrm{Sn}$ & - & - & - \\
\hline & Ilm+Rut + Ana & 35 & 60 & 95 \\
\hline & Zir & 25 & 45 & 70 \\
\hline \multirow{3}{*}{ Blok E } & $\mathrm{Sn}$ & 20 & 30 & 50 \\
\hline & $\mathrm{Ilm}+\mathrm{Rut}+$ Ana & 30 & 45 & 80 \\
\hline & Zir & 30 & 45 & 80 \\
\hline \multirow{3}{*}{ Blok F } & $\mathrm{Sn}$ & 30 & 45 & 70 \\
\hline & $\mathrm{Ilm}+\mathrm{Rut}+\mathrm{Ana}$ & 30 & 45 & 65 \\
\hline & Zir & - & - & - \\
\hline \multirow{3}{*}{ Blok G } & $\mathrm{Sn}$ & 45 & 75 & 120 \\
\hline & $\mathrm{Ilm}+\mathrm{Rut}+$ Ana & 80 & 135 & 205 \\
\hline & Zir & 20 & 35 & 55 \\
\hline \multirow{3}{*}{ Blok H } & $\mathrm{Sn}$ & 40 & 70 & 110 \\
\hline & $\mathrm{Ilm}+\mathrm{Rut}+$ Ana & 65 & 110 & 165 \\
\hline & Zir & 45 & 70 & 110 \\
\hline
\end{tabular}

Tabel 8. Coefficient of variation dari setiap komoditas/mineral.

\begin{tabular}{lcc}
\hline Komoditas/ Mineral & \multicolumn{1}{c}{ Coefficient of Variation } \\
& Range & Mean \\
\hline Sn & $0.90-2.91$ & 1.99 \\
Ilm+Rut+Ana & $0.60-1.36$ & 1.03 \\
Mon & 2.09 & 2.09 \\
Zir & $0.87-3.55$ & 1.91 \\
\hline
\end{tabular}

direkomendasikan untuk dilakukan infill drilling atau perbaikan pola pemboran agar lebih teratur dan dapat dilihat pada Tabel 9.

Berdasarkan nilai daerah pengaruh setiap komoditas/mineral pada Tabel 10, dapat dilihat bahwa secara keseluruhan Sn (timah) memiliki nilai rata-rata daerah pengaruh yang lebih besar daripada mineral ikutan timah (MIT). Hal ini menunjukkan bahwa Sn (timah) di daerah penelitian lebih homogen daripada mineral ikutan timah (MIT). Komoditas/mineral yang paling bervariasi adalah monazite dengan nilai rata-rata daerah pengaruh $60 \mathrm{~m}$. 
Tabel 9. Rekomendasi pada daerah dengan extreme nugget effect.

\begin{tabular}{|c|c|c|c|}
\hline Daerah & Komoditas/ Mineral & Nugget Ratio & Rekomendasi \\
\hline \multirow{4}{*}{ Blok A } & $\mathrm{Sn}$ & $0.7 \%$ & \multirow{4}{*}{-} \\
\hline & $\mathrm{Ilm}+\mathrm{Rut}+\mathrm{Ana}$ & $1 \%$ & \\
\hline & Mon & $1 \%$ & \\
\hline & Zir & $63 \%$ & \\
\hline \multirow{3}{*}{ Blok B } & $\mathrm{Sn}$ & $67 \%$ & \multirow{3}{*}{ Infill Drilling } \\
\hline & $\mathrm{Ilm}+\mathrm{Rut}+$ Ana & $75 \%$ & \\
\hline & Zir & $75 \%$ & \\
\hline \multirow{3}{*}{ Blok C } & $\mathrm{Sn}$ & $9 \%$ & \multirow{3}{*}{-} \\
\hline & $\mathrm{Ilm}+\mathrm{Rut}+\mathrm{Ana}$ & $70 \%$ & \\
\hline & Zir & $48 \%$ & \\
\hline \multirow{3}{*}{ Blok D } & $\mathrm{Sn}$ & $78 \%$ & \multirow{3}{*}{$\begin{array}{l}\text { Perbaikan pola } \\
\text { pemboran agar } \\
\text { lebih teratur }\end{array}$} \\
\hline & $\mathrm{Ilm}+\mathrm{Rut}+\mathrm{Ana}$ & $29 \%$ & \\
\hline & Zir & $57 \%$ & \\
\hline \multirow{3}{*}{ Blok E } & $\mathrm{Sn}$ & $45 \%$ & \multirow{3}{*}{ о } \\
\hline & $\mathrm{Ilm}+\mathrm{Rut}+\mathrm{Ana}$ & $45 \%$ & \\
\hline & Zir & $32 \%$ & \\
\hline \multirow{3}{*}{ Blok F } & $\mathrm{Sn}$ & $35 \%$ & \multirow{3}{*}{$\begin{array}{l}\text { Perbaikan pola } \\
\text { pemboran agar } \\
\text { lebih teratur }\end{array}$} \\
\hline & $\mathrm{Ilm}+\mathrm{Rut}+$ Ana & $30 \%$ & \\
\hline & Zir & $77 \%$ & \\
\hline \multirow{3}{*}{ Blok G } & $\mathrm{Sn}$ & $14 \%$ & \multirow[t]{3}{*}{ 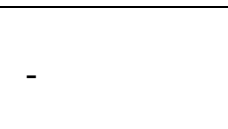 } \\
\hline & Ilm+Rut+Ana & $0.8 \%$ & \\
\hline & Zir & $22 \%$ & \\
\hline \multirow{3}{*}{ Blok H } & $\mathrm{Sn}$ & $40 \%$ & \multirow{3}{*}{-} \\
\hline & $\mathrm{Ilm}+$ Rut+Ana & $17 \%$ & \\
\hline & Zir & $13 \%$ & \\
\hline
\end{tabular}

Tabel 10. Daerah pengaruh (a) setiap komoditas/mineral.

\begin{tabular}{lll}
\hline \multirow{2}{*}{$\begin{array}{l}\text { Komoditas/ } \\
\text { Mineral }\end{array}$} & \multicolumn{2}{c}{ Daerah Pengaruh $(\boldsymbol{a})$} \\
& Range & Mean \\
\hline Sn & $30-120 \mathrm{~m}$ & $78 \mathrm{~m}$ \\
Ilm+Rut + Ana & $45-90 \mathrm{~m}$ & $69 \mathrm{~m}$ \\
Mon & $60 \mathrm{~m}$ & $60 \mathrm{~m}$ \\
Zir & $20-160 \mathrm{~m}$ & $71 \mathrm{~m}$ \\
\hline
\end{tabular}

\section{Spasi lubang bor optimum}

Spasi bor optimum untuk Sn (timah) dan mineral ikutan timah (MIT) berdasarkan 3 (tiga) pendekatan yang digunakan, masing-masing dapat dilihat pada Tabel 11, Tabel 12, dan Tabel 13.

Berdasarkan kriteria Sinclair dan Blackwell (2002) yang dapat dilihat pada Tabel 11, spasi bor optimum untuk Sn (timah) adalah $45 \mathrm{~m}, 75 \mathrm{~m}$, dan
$105 \mathrm{~m}$ berturut-turut untuk kategori measured, indicated, dan inferred. Spasi lubang bor optimum untuk mineral ikutan timah adalah $25 \mathrm{~m}, 40 \mathrm{~m}$, dan $50 \mathrm{~m}$ berturut-turut untuk kategori measured, indicated, dan inferred. Komoditas/mineral dengan spasi lubang bor optimum terkecil dengan menggunakan pendekatan ini adalah monazite.

Berdasarkan pedoman pengklasifikasian sumberdaya PT Timah Tbk. yang dapat dilihat 
Tabel 11. Spasi bor optimum Sn (timah) dan mineral ikutan timah berdasarkan kriteria Sinclair dan Blackwell (2002).

\begin{tabular}{llrlrrr}
\hline \multirow{2}{*}{$\begin{array}{l}\text { Komoditas/ } \\
\text { Mineral }\end{array}$} & \multicolumn{2}{c}{ Measured } & \multicolumn{2}{c}{ Indicated } & \multicolumn{2}{c}{ Inferred } \\
& Range & Mean & Range & Mean & Range & Mean \\
\hline Sn & $30-65$ & 45 & $45-105$ & 75 & $65-150$ & 105 \\
Ilm+Rut+Ana & $40-115$ & 60 & $60-190$ & 100 & $80-260$ & 140 \\
Mon & 25 & 25 & 40 & 40 & 50 & 50 \\
Zir & $30-60$ & 40 & $50-100$ & 70 & $70-140$ & 100 \\
\hline
\end{tabular}

Tabel 12. Spasi bor optimum Sn (timah) dan mineral ikutan timah berdasarkan pedoman pengklasifikasian sumberdaya PT Timah Tbk.

\begin{tabular}{llrlrlr}
\hline \multirow{2}{*}{$\begin{array}{l}\text { Komoditas/ } \\
\text { Mineral }\end{array}$} & \multicolumn{2}{c}{ Measured } & \multicolumn{2}{c}{ Indicated } & \multicolumn{2}{c}{ Inferred } \\
& Range & Mean & Range & Mean & Range & Mean \\
\hline Sn & $20-80$ & 50 & $30-120$ & 75 & $45-180$ & 115 \\
Ilm+Rut+Ana & $30-60$ & 45 & $45-90$ & 65 & $65-135$ & 100 \\
Mon & 40 & 40 & 60 & 60 & 90 & 90 \\
Zir & $35-105$ & 55 & $55-160$ & 85 & $80-240$ & 130 \\
\hline
\end{tabular}

Tabel 13. Spasi bor optimum Sn (timah) dan mineral ikutan timah berdasarkan relative error.

\begin{tabular}{llrlrlr}
\hline \multirow{2}{*}{$\begin{array}{l}\text { Komoditas/ } \\
\text { Mineral }\end{array}$} & \multicolumn{2}{c}{ Measured } & \multicolumn{2}{c}{ Indicated } & \multicolumn{2}{c}{ Inferred } \\
\cline { 2 - 7 } & Range & Mean & Range & Mean & Range & Mean \\
\hline Sn & $20-45$ & 30 & $30-75$ & 55 & $50-120$ & 85 \\
Ilm+Rut+Ana & $30-80$ & 40 & $45-135$ & 70 & $65-205$ & 110 \\
Mon & 20 & 20 & 30 & 30 & 40 & 40 \\
Zir & $20-45$ & 30 & $35-70$ & 50 & $55-110$ & 75 \\
\hline
\end{tabular}

Tabel 14. Perbandingan 3 (tiga) pendekatan optimasi spasi bor.

\begin{tabular}{lllccc}
\hline \multirow{2}{*}{ No. } & \multirow{2}{*}{ Pendekatan Optimasi Spasi Bor } & $\begin{array}{l}\text { Komoditas/ } \\
\text { Mineral }\end{array}$ & \multicolumn{3}{c}{ Spasi Optimum (m) } \\
\cline { 4 - 6 } & & Measured & Indicated & Inferred \\
\hline 1. & Kriteria Sinclair dan Blackwell (2002) & Sn & 45 & 75 & 105 \\
& $\begin{array}{l}\text { (measured 30\%, indicated 50\%, inferred } \\
\text { 70\%) }\end{array}$ & MIT & 25 & 40 & 50 \\
2. & Pedoman Pengklasifikasian Sumberdaya & Sn & 50 & 75 & 115 \\
& PT Timah Tbk. & MIT & 40 & 60 & 90 \\
3. & Relative error (measured 20\%, indicated & Sn & 30 & 55 & 85 \\
& 35\%, inferred 55\%) & MIT & 20 & 30 & 40 \\
\hline
\end{tabular}


pada Tabel 12, spasi bor optimum untuk Sn (timah) adalah $50 \mathrm{~m}, 75 \mathrm{~m}$, dan $115 \mathrm{~m}$ berturutturut untuk kategori measured, indicated, dan inferred. Spasi bor optimum untuk mineral ikutan timah adalah $40 \mathrm{~m}, 60 \mathrm{~m}$, dan $90 \mathrm{~m}$ berturut-turut untuk kategori measured, indicated, dan inferred. Komoditas/mineral dengan spasi bor optimum terkecil dengan menggunakan pendekatan ini adalah monazite.

Berdasarkan nilai relative error pada endapan aluvial yang dapat dilihat pada Tabel 13, spasi bor optimum untuk Sn (timah) adalah $30 \mathrm{~m}, 55 \mathrm{~m}$, dan $85 \mathrm{~m}$ berturut-turut untuk kategori measured, indicated, dan inferred. Spasi bor optimum untuk mineral ikutan timah adalah $20 \mathrm{~m}, 30 \mathrm{~m}$, dan $40 \mathrm{~m}$ berturut-turut untuk kategori measured, indicated, dan inferred. Komoditas/mineral dengan spasi bor optimum terkecil dengan menggunakan pendekatan ini adalah monazite.

Spasi bor optimum untuk masing-masing klasifikasi sumberdaya pada setiap komoditas/mineral yang diperoleh dengan menggunakan 3 (tiga) pendekatan selanjutnya dibandingkan. Perbandingan dari 3 (tiga) pendekatan yang digunakan untuk optimasi spasi bor dapat dilihat pada Tabel 14 .

Berdasarkan perbandingan 3 (tiga) pendekatan optimasi spasi bor pada Tabel 14, dapat dilihat bahwa spasi optimum untuk mineral ikutan timah pada setiap klasifikasi sumberdaya lebih kecil daripada Sn (timah). Hal ini menunjukkan bahwa mineral ikutan timah memiliki variabilitas yang lebih tinggi daripada Sn (timah). Komoditas/mineral yang memiliki variabilitas paling tinggi adalah monazite.

Pedoman pengklasifikasian sumberdaya PT Timah Tbk. untuk komoditas/mineral Sn (timah) hasilnya mendekati pendekatan berdasarkan kriteria Sinclair dan Blackwell (2002). Hal ini menandakan bahwa pedoman pengklasifikasian sumberdaya PT Timah Tbk. untuk Sn (timah) sudah sesuai. Spasi bor optimum untuk Sn (timah) berdasarkan data-data pada 8 (delapan) daerah di Pulau Bangka adalah $45-50$ m, 75 m, dan $105-$ $115 \mathrm{~m}$ berturut-turut untuk kategori measured, indicated, dan inferred.

Untuk mineral ikutan timah, jika menggunakan pedoman pengklasifikasian sumberdaya PT Timah Tbk. (pendekatan ke-2) hasil spasi bor optimum kurang rapat dan berbeda jika dibandingkan dengan pendekatan ke-1 dan ke-3. Hasil spasi optimum dengan menggunakan pendekatan ke-1 dan ke-3 tidak terlalu berbeda jauh. Untuk mineral ikutan timah, spasi bor yang cocok adalah berdasarkan pendekatan ke-1 dan ke-3. Spasi optimum untuk mineral ikutan timah berdasarkan data-data pada 8 (delapan) daerah di Pulau Bangka adalah $20-25 \mathrm{~m}, 30-40 \mathrm{~m}$, dan $40-50$ m berturut-turut untuk kategori measured, indicated, dan inferred.

Pedoman pengklasifikasian sumberdaya PT Timah Tbk. (pendekatan ke-2) hanya memperhitungkan homogenitas dan kontinuitas spasial yang ditunjukkan oleh range/daerah pengaruh $(a)$ variogram. Sedangkan, pendekatan yang menggunakan nilai relative error berdasarkan perhitungan Global Estimation Variance (GEV) seperti pendekatan ke-1 dan ke3 , memperhitungkan variasi kadar pada jarak dekat yang ditunjukkan oleh nilai nugget effect $\left(\mathrm{C}_{0}\right)$, homogenitas dan kontinuitas spasial yang ditunjukkan oleh range/daerah pengaruh $(a)$, dan ukuran wilayah penelitian. Selain itu, pendekatan ke-1 dan ke-3 yang berbasis $G E V$ juga memperhitungan populasi dan variasi dari data kadar yang ditunjukkan oleh kadar rata-rata (mean) dan nilai variance (statistik), dimana nilai sill $\left(\mathrm{C}_{0}+\mathrm{C}_{1}\right)$ merupakan nilai yang mendekati nilai variance.

Spasi bor yang optimum yang dapat mewakili $\mathrm{Sn}$ (timah) dan mineral ikutan timah (MIT) adalah spasi optimum terkecil antara Sn (timah) dan mineral ikutan timah. Berdasarkan data-data pada 8 (delapan) daerah di Pulau Bangka, spasi optimum yang mewakili Sn (timah) dan mineral ikutan timah adalah $20-25 \mathrm{~m}, 30-40 \mathrm{~m}$, dan 40 - $50 \mathrm{~m}$ berturut-turut untuk kategori measured, indicated, dan inferred. Spasi ini diambil dari spasi optimum mineral ikutan timah dikarenakan mineral ikutan timah memiliki spasi optimum yang lebih kecil daripada Sn (timah). Selain itu, mineral ikutan timah juga lebih bervariasi daripada Sn (timah) berdasarkan data-data pada 8 (delapan) daerah di Pulau Bangka.

\section{KESIMPULAN}

Secara statistik maupun secara spasial, mineral ikutan timah (MIT) lebih bervariasi daripada Sn (timah). Hal ini dapat dilihat dari nilai coefficient of variation ( $\mathrm{CoV}$ ) dan range/daerah pengaruh (a) variogram. Selain itu, variabilitas global yang 
dapat dilihat dari hasil Global Estimation Variance $(G E V)$ menunjukkan mineral ikutan timah juga lebih bervariasi daripada Sn (timah). Komoditas/mineral yang paling bervariasi adalah monazite. Sn (timah) secara keseluruhan lebih homogen daripada mineral ikutan timah. Hal ini berarti spasi bor untuk mineral ikutan timah harus lebih rapat daripada $\mathrm{Sn}$ (timah).

Berdasarkan data-data pada 8 (dalapan) daerah di Pulau Bangka, spasi optimum yang mewakili Sn (timah) dan mineral ikutan timah adalah $20-25$ $\mathrm{m}, 30-40 \mathrm{~m}$, dan $40-50 \mathrm{~m}$ berturut-turut untuk kategori measured, indicated, dan inferred. Spasi ini diambil dari spasi optimum mineral ikutan timah dikarenakan mineral ikutan timah lebih bervariasi daripada Sn (timah). Spasi optimum untuk Sn (timah) sendiri adalah $45-50 \mathrm{~m}, 75 \mathrm{~m}$, dan $105-115 \mathrm{~m}$ berturut-turut untuk kategori measured, indicated, dan inferred.

\section{UCAPAN TERIMA KASIH}

Penulis mengucapkan terima kasih kepada PT Timah Tbk. yang telah memberikan dukungan dalam bentuk diskusi dan dataset dalam penelitian ini. Penulis berterima kasih kepada editor dan reviewer yang telah memberikan komentar dan masukan dalam perbaikan naskah tulisan ini.

\section{DAFTAR PUSTAKA}

Battalgazy, N., \& Madani, N., 2019. Categorization of Mineral Resources Based on Different Geostatistical Simulation Algorithms: A Case Study from an Iron Ore Deposit. Natural Resources Research. https://doi.org/10.1007/s1 1053-019-094749

Bern, C. R., Shah, A. K., Benzel, W. M., \& Lowers, H. A., 2016. The distribution and composition of REE-bearing minerals in placers of the Atlantic and Gulf coastal plains, USA. Journal of Geochemical Exploration, $\quad 162$, 50-61. https://doi.org/10.1016/j.gexplo.2015.12.01 1

Bertoli, O., Paul, A., Casley, Z., \& Dunn, D., 2013. Geostatistical drillhole spacing analysis for coal resource classification in the Bowen Basin, Queensland. International Journal of Coal Geology, 112, 107-113. https://doi.org/10.1016/j.coal.2012.12.010
Cornah, A., Vann, J., \& Driver, I., 2013. Comparison of three geostatistical approaches to quantify the impact of drill spacing on resource confidence for a coal seam (with a case example from Moranbah North, Queensland, Australia). International Journal of Coal Geology, 112, 114-124. https://doi.org/10.1016/j.coal.2012.11.006

Evans, A. M., 1993. Ore Geology and Industrial Minerals: An Introduction (Third Edit). Blackwell Publishing.

Geovariances, 2016. Drill Hole Spacing Analysis. Retrieved from https://www.geovariances.com/wpcontent/uploads/2016/07/geovarianceswhite paper-dhsa.pdf.

Gwenzi, W., Mangori, L., Danha, C., Chaukura, N., Dunjana, N., \& Sanganyado, E., 2018. Sources, behaviour, and environmental and human health risks of high- technology rare earth elements as emerging contaminants. Science of the Total Environment, 636, 299 313.

https://doi.org/10.1016/j.scitotenv.2018.04. 235

Heriawan, M. N., Pillayati, P., Widodo, L. E., \& Widayat, A. H., 2020. Drill hole spacing optimization of non-stationary data for seam thickness and total sulfur: A case study of coal deposits at Balikpapan Formation, Kutai Basin, East Kalimantan. International Journal of Coal Geology, 223(March), 103466.

https://doi.org/10.1016/j.coal.2020.103466

Isatelle, F., \& Rivoirard, J., 2019. Mineral Resources classification of a nickel laterite deposit: Comparison between conditional simulations and specific areas. The Southern African Institute of Mining and Metallurgy, 119(October), 871-882.

Journel, A. G., \& Huijbregts, C. J., 1978. Mining Geostatistic. Academic Press. USA.

Matheron, G., 1971. The Theory of Regionalized Variables and Its Applications. Ecole Nationale Superieure des Mines de Paris.

Ng, S. W., Whitehouse, M. J., Roselee, M. H., Teschner, C., Murtadha, S., Oliver, G. J. H., Ghani, A. A., \& Chang, S.-C., 2017. Late Triassic granites from Bangka, Indonesia : A 
continuation of the Main Range granite province of the South-East Asian Tin Belt. Journal of Asian Earth Sciences, 138(March), 548-561. https://doi.org/10.1016/j.jseaes.2017.03.002

Perks, C., \& Mudd, G., 2019. Titanium, zirconium resources, and production: A state of the art literature review. Ore Geology Reviews, 107(July 2018), 629-646. https://doi.org/10.1016/j.oregeorev.2019.02. 025

Purwadi, I., Werff, H. M. A. Van Der, \& Lievens, C., 2020. Targeting rare earth element bearing mine tailings on Bangka Island, Indonesia, with Sentinel-2 MSI. Int J Appl Earth Obs Geoinformation, 88(December 2019), 102055. https://doi.org/10.1016/j.jag.2020.102055

Schwartz, M. O., Rajah, S. S., Askury, A. K., Putthapiban, P., \& Djaswadi, S., 1995. The Southeast Asian Tin Belt. Earth-Science Reviews, 38, 95-293.

Silva, D. S. F., \& Boisvert, J. B., 2014. Mineral resource classification: a comparison of new and existing techniques. Journal of The Southern African Institute of Mining and Metallurgy, 114(March), 265-273.

Sinclair, A. J., \& Blackwell, G. H., 2002. Applied Mineral Inventory Estimation. Cambridge University Press.

Syafrizal, Amertho, S. D., Azwardi, I., Indriati, T., Nabilla, A. O., Suharjo, E. G. W., \& Hede, A. N. H., 2019a. Karakterisasi Mineral Ikutan Timah pada Endapan Primer, Sekunder, dan Tailing di Bangka Selatan dan Belitung. PROSIDING TPT XXVIII PERHAPI 2019 (pp. 807-816).

Syafrizal, Pradana, A. S., Amertho, S. D., Azwardi, I., Heriawan, M. N., \& Hede, A., 2019b. Studi Distribusi Mineral Ikutan Timah (MIT) untuk Mendukung Metoda Penanganan Sampel pada Kegiatan Eksplorasi. PROSIDING TPT XXVIII PERHAPI 2019 STUDI (pp. 797-806).

Yu, S., \& Wai, A. M., 2020. Upgrading of Titanium Dioxide from Ilmenite Concentrate. ETSJ, 02(02), 245-249. 
Sianturi et al.: Analisis Spasi Lubang Bor Untuk Mengevaluasi Sumberdaya Timah Aluvial 